2. With-Profits Schemes

2.0 Background

2.1 Past Performance

2.2 Projections

2.3 Alternative Means of Assessing Life Company Prospects

3. Linked Life Assurance Regular Savings

3.0 Background

3.1 Past Performance

3.2 Future Projections

3.3 Other Points

4. Unit Linked v. With Profits

4.0 Preliminary Considerations

4.1 Past Performance-Global

4.2 Past Performance-Individual Companies

4.3 Past Performance-Continuous Review

4.4 Conclusions

5. Switching

6. Finale

References are cited in footnotes throughout.

\title{
MANAGEMENT DEVELOPMENT
}

\author{
BY N. H. TAYLOR, F.I.A.
}

\section{(Synopsis of a paper presented to the Society on 2 March 1982)}

THE paper provides a brief survey of the subject of management development with some emphasis on the needs of the actuarial profession.

Possible definitions of a manager are given and the subject of management development is split into management education, off the job, and management training, on the job.

The change in attitudes towards management development since the 1950's is discussed.

Two of the many theories on the types of manager are set out, one on individual management style, the other on style in a management team.

A manager's requirements are discussed under the headings personal qualities, technical expertise and organizing ability. The need to diagnose individual needs and the objectives of management development are mentioned.

There is a section of the ways to develop managers; the prerequisites together with the types of course available, the merits of internal and external courses, education methods, debriefing and management development schemes are covered.

An appendix gives information on some of the management courses available. 